\title{
MENINGKATKAN PEMAHAMAN KONSEPTUAL BIOTEKNOLOGI MELALUI HANDOUT DI KAMPUS CEMARA SUMENEP
}

\author{
Dyah Ayu Fajarianingtyas $^{1}$, Jefri Nur Hidayat ${ }^{2}$ \\ Universitas Wiraraja ${ }^{1,2}$ \\ e-Mail: tanzilkurnain@gmail.com ${ }^{1}$
}

\begin{abstract}
ABSTRAK
Pemahaman konseptual merupakan aspek kunci dari pembelajaran. Kesulitan dalam memahami konsep dasar dengan tepat akan menghambat mahasiswa mengingat fakta yang terpisah sehingga tidak dapat mengkaitkan konsep tersebut dalam kehidupan sehari-hari. Penelitian ini bertujuan (1) untuk menghasilkan bahan ajar berupa handout melalui adaptasi metode pengembangan Research and Development $(R \& D)$; dan (2) mengetahui peningkatan pemahaman konsep mahasiswa setelah menggunakan handout Bioteknologi;. Penelitian ini merupakan penelitian pengembangan. Metode pengembangan penelitian menggunakan metode R\&D meliputi: (1) potensi dan masalah, (2) Pengumpulan Data, (3) Desain produk, (4) Validasi desain, (5) Revisi desain, (6) Uji coba Pemakaian, dan (7) Revisi Produk. Instrumen penelitian yang digunakan adalah pretest dan posttest. Data dianalisis menggunakan uji t. Hasil penelitian menunjukkan bahwa (1) bahan ajar berupa handout memenuhi kriteria validasi sebesar 90\% dengan kualifikasi sangat baik; (2) Hasil Uji t sebesar 10.163 menyatakan bahwa ada perbedaan peningkatan hasil pretest dan posttest secara nyata. Penggunaan handout Bioteknologi mampu meningkatkan pemahaman konsep mahasiswa sebesar 33\%. Nilai rata-rata Bioteknologi Lingkungan mencapai 80.66 dan Bioteknologi Medis mencapai 85.82.
\end{abstract}

Kata kunci: Handout, Bioteknologi, Pemahaman Konsep.

\section{PENDAHULUAN}

Bioteknologi merupakan salah satu mata kuliah Pendidikan IPA di kampus Cemara Sumenep yang selama ini jarang diminati mahasiswa. Hasil wawancara mahasiswa berpendapat bahwa perkuliahan Bioteknologi memiliki materi kompleks untuk ditelaah dalam kehidupan sehari-hari, kesulitan memahami bahasa latin saat membaca konsep yang berkenaan materi biologi, tidak memahami prinsip-prinsip bioteknologi dalam aktivitas ilmiah yang disajikan melalui bentuk gambar atau tulisan, dan referensi bioteknologi bahasa Indonesia dalam jumlah terbatas.

Hasil analisis studi pendahuluan yang dilakukan di Kampus Cemara diketahui bahwa hasil Ujian Tengah Semester (UTS) Tahun 2014 pada materi lingkungan dan medis memperoleh nilai rata-rata 67.93 (kategori C). Salah satu faktor penyebab rendahnya hasil belajar mahasiswa adalah mahasiswa kurang aktif mengkonstruksikan pengetahuan secara mandiri. Kondisi ini disebabkan oleh minimnya bahan ajar Bioteknologi yang tersedia.

Salah satu kompetensi yang perlu dimiliki seorang dosen dalam melaksanakan tugasnya adalah mengembangkan bahan ajar. Pengembangan bahan ajar penting dilakukan dosen agar pembelajaran lebih efektif, efisien, dan mencapai kompetensi. Oleh karena itu bahan ajar merupakan hal yang sangat penting untuk dikembangkan sebagai upaya meningkatkan kualitas pembelajaran.

Pemahaman konsep merupakan salah satu indikator keberhasilan belajar kognitif. Motivasi mahasiswa untuk mengingat materi melalui pemahaman. Penyandian sebagian besar informasi ke 
memori dapat dilakukan dengan memberikan konsep dan ide dengan pengalaman dan makna personal. Mahasiswa dapat belajar dengan latihanlatihan untuk mengelaborasi suatu konsep agar dapat memproses informasi secara lebih mendalam (Santrock, 2004).

Bahan ajar yang akan dikembangkan di Kampus Cemara Sumenep adalah handout. Pengembangan bahan ajar yang tepat dan sesuai kebutuhan mahasiswa adalah salah satu upaya terbaik untuk meningkatkan hasil belajar. Hal ini didukung oleh hasil penelitian Hera (2014) bahwa penggunaan handout pada perkuliahan Perkembangan Hewan di Universitas Muhammadiyah Banda Aceh mampu meningkatkan pemahaman konsep mahasiswa berkisar antara $66 \%$ sampai $83 \%$.

Handout (HO) adalah "segala sesuatu" yang diberikan kepada mahasiswa ketika mengikuti kegiatan perkuliahan. HO dimaksudkan untuk memperlancar dan memberikan bantuan informasi atau materi pembelajaran sebagai pegangan bagi mahasiswa. $\mathrm{HO}$ dapat digunakan untuk beberapa kali pertemuan yang tergantung dari desain dan lama waktu untuk penyelesaian satuan perkuliahan tersebut (Badan Pengembangan Akademik Universitas Islam Indonesia, 2009). Fungsi handout adalah membantu peserta didik agar tidak perlu mencatat, sebagai pendamping penjelasan pendidik, sebagai bahan rujukan peserta didik, memotivasi peserta didik agar lebih giat belajar, pengingat pokok-pokok materi yang diajarkan, memberi umpan balik, dan menilai hasil belajar (Prastowo, 2014).

Tujuan penelitian ini adalah (1). Menghasilkan bahan ajar berupa handout melalui adaptasi metode pengembangan Research and Development (R\&D) dan (2). Mengetahui peningkatan pemahaman konsep mahasiswa setelah menggunakan handout Bioteknologi.

\section{METODE PENELITIAN}

Metode pengembangan dalam penelitian menggunakan Research and Development (R\&D). Desain uji coba penelitian ini menggunakan One-group Pretest-Posttest Design (Pretest-Posttest kelompok tunggal). Subjek penelitian adalah mahasiswa Pendidikan IPA semester Genap tahun ajaran 2014-2015 sebanyak 38 mahasiswa. Tempat Penelitian dan pengembangan ini dilakukan di Universitas Wiraraja (Kampus Cemara). Waktu Penelitian ini dilaksanakan pada bulan April 2015 sampai Juli 2015.

Prosedur pengembangan produk handout bioteknologi dalam penelitian ini terdiri atas tujuh tahapan karena keterbatasan waktu dan sumber daya. Secara ringkas menjelaskan langkahlangkah R\&D terlihat pada Gambar 1.

Instrumen yang digunakan untuk mengumpulkan data penelitian dan pengembangan bahan ajar handout adalah tes. Teknik analisis data yang digunakan adalah teknik analisis deskriptif kuantitatif. Data dianalisis menggunakan uji-t sampel berpasangan.

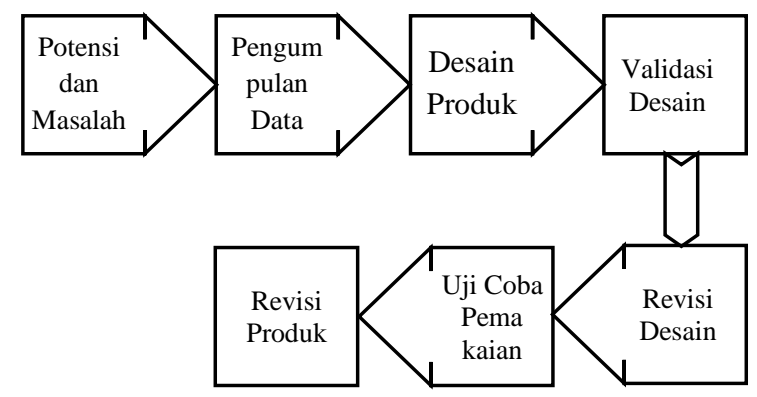

Gambar 1. Langkah-Langkah R\&D

Tahapan Pengembangan Handout Bioteknologi di kampus Cemara Sumenep adalah sebagai berikut (Putra, 2011).

1. Tahap Potensi dan Masalah

Tahap ini dimulai dari melakukan wawancara terhadap dosen IPA dan mahasiswa untuk mengumpulkan informasi. Potensi dan masalah dalam penelitian ini adalah 
identifikasi permasalahan yang ditemui dalam pembelajaran yang didapatkan dari pengamatan kelas maupun dokumentasi laporan nilai mahasiswa angkatan 2009-2011.

2. Pengumpulan Data

Pengumpulan data dilakukan setelah potensi dan masalah yang dapat digunakan sebagai bahan untuk perencanaan. Pengumpulan data dilakukan melalui pengujian tes untuk mengetahui peningkatan pemahaman konsep Bioteknologi. Referensi yang digunakan dalam tahap pengembangan handout adalah silabus, Satuan Acara Perkuliahan (SAP), kontrak kuliah, petunjuk praktikum, jurnal ilmiah, buku, dan rangkuman permasalahan. Dalam penyusunan bahan ajar handout dibatasi Bioteknologi Lingkungan dan Medis. Hasil dari pengumpulan data digunakan sebagai bahan untuk perencanaan pengembangan handout bioteknologi.

3. Desain Produk

Hasil akhir penelitian ini berupa produk. Tahap ini mendesain produk bahan ajar berupa handout bioteknologi diperlukan adanya perencanaan yang meliputi:

a. Analisis Sebaran Kompetensi

Tahap ini dosen melakukan komparasi antara kompetensi yang harus diajarkan dalam setengah semester dengan alokasi waktu yang tersedia. Hasil analisis komparasi tersebut adalah penentuan alokasi waktu untuk kompetensi dasar. Dosen perlu mempertimbangkan tingkat kesulitan dan kompleksitas setiap KD yang diajarkan. Pada penelitian ini mengembangkan bahan ajar handout mengikuti kontrak kuliah, silabus dan SAP yang dibuat dengan alokasi waktu yang ditetapkan di Kampus Cemara yaitu tatap muka dengan alokasi waktu 50 menit/sks. b. Analisis Mahasiswa

Tingkatan perkembangan kognitif dapat diprediksi melalui tingkatan kelas mahasiswa dan lebih tepatnya berdasarkan hasil pengamatan dosen pengampu mata kuliah. Ditinjau dari perkembangan kognitif, mahasiswa IPA di Kampus cemara berada pada tahap operasional formal yaitu berpikir secara lebih abstrak, idealistik, dan logis. Implikasi pendidikan yang dapat dilakukan adalah mendorong mahasiswa untuk aktif bertanya, mengemukakan ide, uji coba suatu materi, melakukan dialog, diskusi dalam pemecahan masalah.

c. Analisis Instruksional

Pada tahap ini dosen pengampu mata kuliah menyusun analisis struktur isi, analisis konsep, dan analisis prosedural untuk mencapai tujuan instruksional. Analisis struktur isi mencakup kompetensi dasar yang akan diajarkan diuraikan menjadi kompetensi yang lebih spesifik yaitu pada tujuan pembelajaran. Analisis konsep berisi konsep utama yang disusun secara sistematis untuk mencapai kompetensi dasar. Analisis Prosedural mencakup penentuan tugas atau aktivitas yang akan dilakukan mahasiswa selama pembelajaran berlangsung. Tugas yang diberikan harus sesuai untuk mendukung kompetensi.

d. Penyusunan Bahan Ajar Handout Hasil setiap analisis yang dilakukan pada tahap sebelumnya akan diimplementasikan ke dalam penyusunan bahan ajar berupa handout bioteknologi (draft 1) untuk mendukung dosen pengampu mata kuliah melaksanakan proses belajar mengajar. 
4. Validasi Desain

Validasi desain merupakan kegiatan untuk menilai keefektifan rancangan produk. Pada penelitian ini validasi produk dilakukan oleh para ahli yang telah pengalaman untuk menilai handout bioteknologi berdasarkan pemikiran rasional. Validasi desain dilakukan dalam forum diskusi kemudian dilakukan penilaian oleh dosen mitra yang berpengalaman penyusunan bahan ajar. Validasi produk dinilai oleh satu dosen kualifikasi S3 bidang MIPA dan satu dosen kualifikasi S2 bidang Pendidikan IPA. Validasi desain dinilai oleh satu dosen kualifikasi S3 bidang pendidikan bahasa dan satu dosen kualifikasi S2 bidang pendidikan IPA. Hasil validasi digunakan sebagai dasar untuk melakukan perbaikan terhadap produk pengembangan.

5. Revisi Desain

Pada tahap ini dihasilkan handout (draft 2) setelah dilakukan validasi oleh para ahli. Kelemahan atau kekurangan handout (draft 1) akan dicoba untuk dikurangi dengan cara memperbaiki desain. Desain produk baru siap digunakan untuk uji coba pemakaian.

6. Uji Coba Pemakaian

Tahap ini melakukan implementasi pembelajaran menggunakan handout. Desain uji coba yang digunakan penelitian ini adalah One-group Pretest-Posttest Design (PretesPostes kelompok tunggal). PretesPostes pada penelitian ini menggunakan tes soal yang sama bentuk pilihan ganda. Pretest dilakukan untuk mengetahui pengetahuan awal mahasiswa. Postest dilakukan untuk mengetahui pemahaman siswa setelah menggunakan handout. .

7. Revisi Produk

Tahap ini melakukan revisi terhadap produk operasional berdasarkan saran-saran dari hasil uji coba pemakaian. Hasil uji coba didapatkan adalah hasil pemahaman konsep menjadi perbaikan revisi produk yang telah dibuat. Hasil revisi produk berupa handout Bioteknologi.

\section{HASIL DAN PEMBAHASAN}

Data yang diperoleh pada penelitian Meningkatkan Pemahaman Konseptual Bioteknologi Melalui Handout di Kampus Cemara Sumenep adalah sebagai berikut.

1. Tahap Potensi dan Masalah

Permasalahan yang terjadi pada pembelajaran Bioteknologi di Prodi Pendidikan IPA adalah hasil Ujian Tengah Semester (UTS) Tahun 2014 pada materi lingkungan dan medis memperoleh nilai rata-rata 67.93 (kategori C). Salah satu faktor penyebab rendahnya hasil belajar mahasiswa adalah mahasiswa kurang aktif mengkonstruksikan pengetahuan secara mandiri. Kondisi ini disebabkan oleh minimnya bahan ajar Bioteknologi yang tersedia. Potensi yang dimiliki adalah seorang dosen melalui kompetensi profesionalnya harus mampu mewujudkan langkah-langkah pembelajaran inovatif, progresif, dan kreatif sehingga proses belajar mengajar dapat bermakna. Selain itu, dukungan layanan perpustakaan melalui e-book maupun e-journal mempermudah dosen untuk mencari sumber referensi penyusunan handout. Berdasarkan hasil identifikasi masalah dirumuskan beberapa hal yang menjadi kebutuhan mahasiswa Pendidikan IPA di kampus Cemara adalah dibutuhkan bahan ajar yang menguraikan konsep-konsep secara sistematis dengan tampilan ringkas sehingga mudah diingat dan dibutuhkan bahan ajar yang 
mengintegrasikan materi dengan fakta-fakta dalam kehidupan.

2. Pengumpulan Data

Standar Kompetensi yang terpilih yaitu menjelaskan penerapan bioteknologi dalam berbagai bidang kehidupan manusia. Kompetensi Dasar yang terpilih ada dua meliputi menjelaskan penerapan Bioteknologi Lingkungan dan menjelaskan penerapan Bioteknologi Medis. Materi handout terdiri atas Bioremediasi dan Fitoremediasi, vaksin, antibodi monoklonal, stem cell, dan terapi gen.

3. Desain Produk

Pengembangan produk berupa Handout yang terdiri atas materi Bioremediasi dan Fitoremediasi, vaksin, antibodi monoklonal, stem cell, dan terapi gen. Tugas-tugas yang diberikan berisi isu-isu kontekstual bentuk soal uraian.

4. Validasi Desain

Berdasarkan hasil penelitian diketahui bahwa rancangan handout Bioteknologi menurut penilaian validator memiliki kualifikasi sangat baik dan dapat digunakan dalam perkuliahan Bioteknologi. Angka persentase tersebut dapat dilihat pada Tabel 1 sebagai berikut.

Tabel 1. Hasil Uji Validasi Handout Bioteknologi

\begin{tabular}{llc}
\hline Validator & Persentase & Kategori \\
\hline Materi & 88 & Sangat baik \\
Bahasa & 93 & Sangat baik \\
Gabungan & 90 & Sangat baik \\
\hline
\end{tabular}

Dengan demikian, rancangan handout perkuliahan Bioteknologi yang telah dievaluasi oleh validator secara keseluruhan tidak perlu dilakukan revisi. Namun, revisi tetap dilakukan berdasarkan saran yang diberikan setiap ahli baik yang disampaikan secara langsung maupun saran tertulis yang ada di kolom saran. Handout Bioteknologi kemudian dicetak dan diimplementasikan dalam perkuliahan Bioteknologi pada materi Lingkungan dan Medis.

5. Revisi Desain

Uji validasi dilakukan sebagai upaya untuk menghasilkan bahan ajar yang baik dan relevan dengan landasan teoritik pengembangan (Akbar, 2013). Hasil penelitian menunjukkan bahwa bahan ajar yang dikembangkan di kampus Cemara mencapai $90 \%$ dengan kualifikasi sangat baik. Hal ini menunjukkan bahwa handout Bioteknologi dapat digunakan dalam perkuliahan. Pengajaran dengan menggunakan handout merupakan usaha penyelenggaraan pengajaran individual yang memungkinkan mahasiswa secara mandiri mengkonstruksi konsep-konsep dari satu unit materi pembelajaran atau lebih sesuai dengan isi rancangan handout tersebut.

6. Uji Coba Pemakaian

Hasil uji hipotesis pemahaman konsep melalui Handout disajikan pada Tabel 2.

Tabel 2. Hasil Uji Pemahaman Konsep

\begin{tabular}{lcccc}
\hline Data & $\mathbf{T}_{\text {hit }}$ & $\mathbf{T}_{\text {tabel }}$ & Sign & Alpha \\
\hline $\begin{array}{l}\text { Pair } \\
\text { Posttest }-\end{array}$ & $\mathbf{1 0 , 1 6 3}^{*}$ & 1,645 & $0,000^{*}$ & 0,05 \\
Pretest & & & & \\
\hline
\end{tabular}

\begin{tabular}{lcc}
\hline \multicolumn{1}{c}{ Data } & Keputusan & Kesimpulan \\
\hline $\begin{array}{l}\text { Pair } \\
\text { Posttest }-\end{array}$ & Tolak $\mathbf{H}_{\mathbf{0}}$ & $\begin{array}{c}\text { Terdapat } \\
\text { perbedaan pretest } \\
\text { Pretest }\end{array}$ \\
$\begin{array}{l}{ }^{*} \text { Output } \text { Paired Samplest } \\
\text { Ores Test }\end{array}$
\end{tabular}

Tabel 2 menunjukkan nilai thitung hasil pemahaman konsep sebesar 10.163 dengan nilai signifikansi 0.000. Hasil penelitian menunjukkan bahwa ada perbedaan peningkatan hasil pretest dan posttest secara 
nyata. Pemahaman konsep adalah kemampuan untuk menangkap makna dari bahan yang dipelajari/hasil dari proses pembelajaran. Kemampuan ini dinyatakan dalam menguraikan isi pokok dari suatu bacaan; mengubah data yang disajikan dalam bentuk tertentu ke bentuk lain; membuat perkiraan tentang kecenderungan yang nampak dalam data tertentu seperti grafik. Hasil belajar kognitif mahasiswa berkaitan dengan kemampuan mahasiswa dalam menerima dan memahami materi dalam pembelajaran. Konsep pembelajaran mencakup pengenalan sifat-sifat, menggeneralisirnya ke dalam contoh-contoh baru, dan memisahkan contoh-contoh dari non contoh (Schunk, 2012).

7. Revisi Produk

Tahap ini peneliti melakukan revisi terhadap produk operasional berdasarkan saran-saran dari hasil uji pemakaian. Hasil revisi produk berupa handout Bioteknologi.

\section{Peningkatan Pemahaman Konsep}

Penggunaan handout Bioteknologi mampu meningkatkan pemahaman konsep mahasiswa sebesar 33\%. Pada perkuliahan ini, mahasiswa dilatih untuk mengkonstruksi pengetahuan melalui penyelesaian isu permasalahan yang berkaitan dengan kehidupan sehari-hari. Pada penyajian handout Bioteknologi yang dikembangkan ini meliputi pera konsep, mekanisme kerja,perkembangan bioteknologi, aplikasi, dampak maupun manfaat bioteknologi disajikan secara sistematis dalam bentuk contoh gambar yang berbeda maupun analisis isu-isu kontekstual. Pengajaran dengan bahan ajar handout dapat membantu mahasiswa secara mandiri mengkonstruksi konsepkonsep sehingga dapat menjembatani pengetahuan teori dengan pengalaman nyata.
Dalam mengajarkan konsep, menampilkan contoh yang berbeda dalam sifat-sifat opsional, tetapi memiliki sifatsifat yang terkait merupakan hal yang bermanfaat agar sifat-sifat yang terkait itu dapat ditunjukkan dengan jelas bersamaan dengan dimensi yang tidak berkaitan (Schunk, 2012). Tubuh manusia terstruktur sehingga informasi dapat masuk lebih banyak melalui indra penglihatan dibandingkan melalui keempat indra lainnya (Wolfe, 2001). Tampilan-tampilan visual membantu meningkatkan perhatian, pembelajaran, dan mempertahankannya. Ada berbagai cara untuk mempelajari dan memodifikasi konsep. Cara pertama adalah mengembangkan prototipe ialah dihadapkan pada contoh biasa mengenai konsep yang mencerminkan sifat-sifat klasik dan cara kedua adalah mengabstraksi fitur-fitur dari dua atau lebih contoh (Klausmeier, 1992).

Teknis penyajian materi handout yang ringkas dan mudah diingat serta adanya pengembangan isu-isu kontekstual menjadikan bahan ajar tersebut menjadi bermakna. Bahan ajar ini berisi rangkuman konsep-konsep penting dari suatu materi sehingga dapat memudahkan pembaca menguasai, memahami, dan mengingat konsepkonsep yang dipelajari (Sanaky, 2011). Selaras dengan penjelasan sebelumnya bahwa materi kompleks apabila dikemas secara ringkas membantu mahasiswa untuk memahami konsep. Prastowo (2014) handout adalah bahan ajar yang sangat ringkas bersumber dari beberapa literatur yang relevan terhadap kompetensi dasar dan materi pokok yang diajarkan. Bahan ajar ini ekonomis dan praktis untuk memudahkan peserta didik mengikuti proses pembelajaran.

Pada handout bioteknologi yang dikembangkan di Kampus Cemara terdapat soal-soal latihan di setiap akhir bab sebagai umpan balik yang dilengkapi dengan soal pemahaman sebagai alat evaluasi. Pengajaran bisa disebarkan pada 
beberapa tingkat dimana konsep-konsep di cek kembali secara berkala pada tingkat pencapaian yang lebih tinggi (Schunk, 2012). Rata-rata nilai pemahaman konsep mahasiswa ditunjukkan Gambar 2 berikut ini.

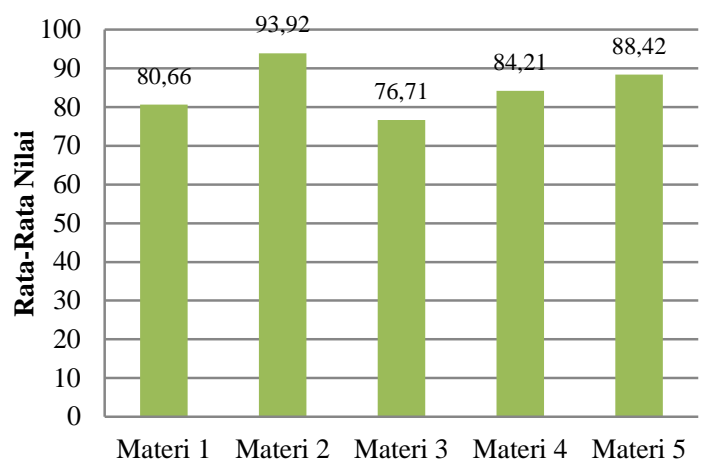

Keterangan :

Materi 1 : Bioremediasi dan Fitoremediasi Materi 2: Vaksin

Materi 3 : Antibodi Monoklonal

Materi 4 : Stem Cell

Materi 5 : Terapi Gen

Gambar 2. Nilai rata-rata mahasiswa materi biologi Lingkungan dan Medis

Hal ini dapat dilihat dari hasil penelitian bahwa nilai rata-rata untuk materi Bioteknologi Lingkungan mencapai 80.66 pada pertemuan pertama. Nilai rata-rata untuk materi Bioteknologi Medis mencapai 85.82 pada pertemuan kedua. Prastowo (2014) menyatakan bahwa fungsi handout sebagai bahan rujukan mahasiswa, memberi umpan balik, dan menilai hasil belajar. Handout dapat berisi penjelasan, pertanyaan dan kegiatan mahasiswa, dan pemberian umpan balik. Oleh karena itu, melalui handout dapat digunakan sebagai alat evaluasi.

Meece dan Miller (2001) mendapati bahwa sasaran penguasaan tugas memprediksi penggunaan strategi belajar oleh mahasiswa dalam pengajaran membaca melalui Handout. Pernyatan tersebut sesuai dengan hasil respon mahasiswa sebesar $97 \%$ yang berpendapat bahwa soal-soal latihan pada bagian akhir bab membantu mahasiswa mengetahui sejauh mana pemahaman mahasiswa terhadap materi pembelajaran.

Pembelajaran sains yang dikembangkan dosen secara variatif dapat membekali kemampuan mahasiswa dalam hal pemahaman konsep, keterampilan proses sains dan kemampuan berargumentasi. Pengalaman ini mengkondisikan dosen agar lebih pragmatis, praktis, efisien dan fokus pada target utama pembelajaran dalam setiap tahap-tahap pelaksanaan pembelajaran. Hasil penelitian Faizah (2014) Handout Fisika berbasis guided note taking dapat meningkatkan motivasi belajar peserta didik kelas $\mathrm{X}$ dan dapat digunakan sebagai alternatif pembelajaran pada tingkat SMA. Hasil penelitian serupa yang berkaitan dengan handout adalah hasil penelitian Helmanda (2012) bahwa handout berbasis pendekatan realistik yang dikembangkan memiliki karakteristik sangat valid ditinjau dari segi isi, konstruksi, teknik, penulisan, dan penggunaan bahasa.

\section{KESIMPULAN}

Hasil penelitian menunjukkan bahwa (1) bahan ajar berupa handout memenuhi kriteria validasi sebesar $90 \%$ dengan kualifikasi sangat baik; (2) Hasil Uji t sebesar 10.163 menyatakan bahwa ada perbedaan peningkatan hasil pretest dan posttest secara nyata. Penggunaan handout Bioteknologi mampu meningkatkan pemahaman konsep mahasiswa sebesar 33\%. Nilai rata-rata Bioteknologi Lingkungan mencapai 80.66 dan Bioteknologi Medis mencapai 85.82 .

\section{DAFTAR PUSTAKA}

Akbar, S. 2013. Instrumen Perangkat Pembelajaran. Bandung : PT Remaja Rosdakarya. 
Badan Pengembangan Akademik Universitas Islam Indonesia. 2009. Panduan Pembuatan Bahan Ajar (Diktat, Modul, Handout). Yogyakarta: Universitas Islam Indonesia.

Helmanda, R. 2012. Pengembangan Handout Matematika Berbasis Pendekatan Realistik Untuk Siswa SMP Kelas VII Semester 2. Jurnal Pendidikan Matematika, 1 (1), 7579.

Hera, R. 2014. Pengembangan Handout Pembelajaran Embriologi Berbasis Kontekstual Pada Perkuliahan Perkembangan Hewan Untuk Meningkatkan Pemahaman Konsep Mahasiswa di Universitas Muhammadiyah Banda Aceh. Jurnal EduBio Tropika, 2 (2), 187250.

Faizah, A. 2014. Pengembangan Handout Fisika Berbasis Guided Note Taking Guna Meningkatkan Motivasi Belajar Siswa Kelas X Di SMA Negeri 3 Purworejo Tahun Pelajaran 2013/2014. Jurnal Radiasi, 5 (2), 53-57.

Klausmeier, H. J. 1992. Concept Learning and Concept Teaching. Educational Psychologist, 27, 267286.

Meece, J.L.,\& Miller, S.D. 2001. A longitudinal analysis of elementary school students achievements goals in literacy activities. Contemporary Educational Psychology, 26, 454480.

Putra, N. 2011. Research \& Development Penelitian dan Pengembangan: Suatu Pengantar. Jakarta : PT RajaGrafindo Persada.

Prastowo, A. 2014. Panduan Kreatif Membuat Bahan Ajar Inovatif. Yogyakarta: Diva Press.

Sanaky, H. 2011. Media Pembelajaran. Yogyakarta : Kaukaba Dipantar.
Schunk, D, H. 2012. Learning Theories An Educational Perspective (TeoriTeori Pembelajaran:Perspektif Pendidikan). Yogyakarta: Pustaka Belajar.

Santrock, J. W. 2004. Educational Psychology. Jakarta: Kencana Prenada Media Group.

Wolfe, P. 2001. Brain matters. Translating research into classroom practice. Alexandra, VA: Association for Supervision And Curriculum Development. 